\title{
STRATEGI GURU DALAM MENGATASI KESULITAN BELAJAR MATEMATIKA PADA MASA PANDEMI COVID-19DI MI NW KARANG BATA KOTA MATARAM
}

\author{
Rizki Isma Wulandari ${ }^{1}$, Siti Ruqoiyyah ${ }^{2}$ \\ ${ }^{1}$ Pendidikan Guru Madrasah Ibtidaiyah, Universitas Islam Negeri Mataram \\ ${ }^{2}$ Pendidikan Guru Madrasah Ibtidaiyah,Universitas Islam Negeri Mataram \\ *Corresponding author:sitiruqoiyyah@uinmataram.ac.id
}

\begin{abstract}
Abstrak
Penelitian ini dilatarbelakangi oleh perhatian peneliti terhadap kesulitan belajar matematika pada masa pandemi Covid-19. Dengan adanya kesulitan belajar siswa, maka perlu adanya strategi yang tepat dari guru dalam mengatasi kesulitan tersebutPenelitian ini menggunakan pendekatan kualitatif dengan jenis penelitian deskriptif. Adapun metode pengumpulan data dilaksanakan melalui wawancara, observasi, dan dokumentasi. Analisis data dilakukan dengan memberikan makna terhadap data yang telah berhasil dikumpulkan, sedangkan teknik keabsahan data dilakukan dengan menggunakan triangulasi teknik, waktu dan sumber.Hasil penelitian ini menunjukkan bahwa:strategi guru dalam mengatasi kesulitan belajar matematika pada masa pandemi Covid-19 di kelas IV MI NW Karang Bata adalah dengan menerapkan strategi pembelajaran Ekspositori dan strategi pembelajaran Kooperatif. Selain itu strategi guru kelas IV yang membedakan dengan guru lain adalah (a) guru memastikan kesiapan belajar siswa, (b) guru menggunakan media pembelajaran dengan benda-benda nyata, (c) permasalahan yang diberikan merupakan permasalahan dalam kehidupan sehari-hari, (d) tingkat kesulitan masalah sesuai dengan kemampuan anak, dan (e) memberi kebebasan kepada anak untuk menyelesaikan masalah, serta (f) menghilangkan rasa takut siswa untuk belajar matematik
\end{abstract}

Katakunci: Kesulitan Belajar Matematika; Pandemi Covid-19; Strategi Guru

\section{PENDAHULUAN}

Pada saat ini siswa tidak dapat melakukan proses belajar di sekolah karena adanya pandemi Covid-19. Sejak wabah Covid-19 masuk ke Indonesia proses pembelajaran berlangsung tidak optimal, namun hal ini tidak menghalangi siswa untuk tetap melaksanakan proses belajarmengajar. Oleh karena itu, proses pembelajaran beralih dengan siswa belajar dari rumah melalui bantuan orang tua dan bimbingan guru secara jarak jauh. Hal ini dijelaskan dalam Surat Edaran Nomor 4 Tahun 2020 Tentang Pelaksanaan Kebijakan Pendidikan dalam Masa Darurat Penyebaran Virus, bahwa Menteri Pendidikan dan Kebudayaan Indonesia menghimbau agar semua lembaga pendidikan tidak melakukan proses pembelajaran secara langsung atau tatap muka, tetapi pembelajaran harus dilakukan secara jarak jauh atau daring. ${ }^{1}$

Ssaat ini aktivitas belajar-mengajar dilakukan secara daring. Hal ini sangat berpengaruh pada kegiatan belajar siswa terutama pada mata pelajaran matematika. Dalam proses pembelajaran matematika di masa daring, guru perlu memberikan penjelasan dan pemahaman secara gamblang untuk dapat menyampaikan materi dengan jelas dan mudah dipahami siswa.

1 "Surat Edaran Mendikbud No. 2 Tahun 2020 Tentang Pelaksanaan Kewajiban Pendidikan Dalam Masa Darurat Penyebab Corona Virus Disease (Covid-19), Pusdiklat Pegawai Kementrian Pendidikan dan Kebudayaan, 24 Maret 2020", dalam https://pusdiklat.kemdikbud.go.id/surat-edaranmendikbud-no-4-4tahun-2020-tentang-pelaksanaan-kebijakan-pendidikan-dalam-masa-daruratpenyebarab-corona-virus-disease-Covid-19/. Diakses tanggal 01 April 2021, pukul 10.01 WITA. 
Menurut Susanto matematika adalah salah satu disiplin ilmu yang dapat meningkatkan kemampuan berpikir siswa dan berargumentasi, memberi kontribusi dalam menyelesaikan masalah sehari-hari serta dapat memberikan dukungan dalam mengembangkan ilmu pengetahuan dan teknologi. ${ }^{2}$ Namun pada masa pandemi Covid-19 ini kemampuan siswa dalam berpikir, berargumentasi, menyelesaikan masalah maupun mengembangkan IPTEK tidak dapat berlangsung sebagaimana mestinya. siswa mengalami banyak kendala dan hamBatan dalam hal belajar, kendala yang dialami siswa dalam proses pembelajaran matematika di masa pandemi Covid-19 ini dapat dilihat dari berbagai faktor seperti dari aspek profesionalisme guru, keterbatasan sarana dan prasarana untuk pembelajaran daring, ataupun faktor internal siswa dan orang tua. Kendala atau hambatan siswa dalam belajar inilah yang disebut dengan kesulitan belajar.

Dalam mengatasi kesulitan belajar siswa pada pembelajaran matematika diperlukan sosok seorang guru yang berperan penting. Salah satu peran yang dilakukan oleh guru adalah mengambil strategi yang tepat, strategi tersebut adalah guru perlu meningkatkan kemampuannya untuk mengatasi kesulitan siswa dalam belajar matematika. Upaya ini dapat berupa guru menerapkan beberapa strategi yang dilakukan dalam proses pembelajaran daring secara efektif dan menyenangkan, sehingga siswa dapat memahami materi dengan mudah, tidak membosankan dan tidak terbebani dengan banyak tugas.

Faktanya, berdasarkan hasil wawancara dengan guru kelas IV MI NW Karang Bata Kota Mataram menunjukkan bahwa proses pembelajaran di masa pandemi Covid-19 ini sebagian besar siswa mengalami kesulitan belajar khususnya dalam mata pelajaran matematika yang disebabkan oleh faktor kurangnya kemampuan siswa memahami materi pembelajaran, malasnya siswa dalam mengoperasikan bilangan, dan siswa lebih banyak waktu untuk bermain daripada belajar, serta orang tua yang terlalu sibuk bekerja sehingga tidak fokus mengontrol proses belajar anak. ${ }^{3}$

Selain itu berdasarkan dokumentasi penilaian hasil belajar siswa kelas IV MI NW Karang Bata terdapat penurunan. Hal ini dapat dilihat dari hasil nilai murni Ujian Akhir Semester (UAS) sebelum adanya pandemi Covid-19 dan setelah adanya pandemi Covid-19. Berdasarkan dokumentasi tersebut diperoleh hasil data yaitu jumlah siswa yang tidak lulus Kriteria Ketuntasan Minimal (KKM) pada Ujian Akhir Semester Ganjil mata pelajaran matematika sebelum pandemi Covid-19 sebanyak enam siswa dari jumlah keseluruhan 22 siswa di kelas IV MI NW Karang Bata. Sedangkan jumlah siswa yang tidak lulus KKM pada Ujian Akhir Semester Genap mata pelajaran matematika setelah adanya pandemi Covid-19 sebanyak 17 siswa dari jumlah keseluruhan 22 siswa di kelas IV MI NW Karang Bata dengan standar KKM sebesar $6,5 .^{4}$

Berdasarkan permasalahan yang telah dipaparkan di atas, maka peneliti tertarik untuk melakukan penelitian lebih lanjut dengan judul "Strategi Guru Dalam Mengatasi Kesulitan Belajar Matematika Pada Masa Pandemi Covid-19di Kelas IV MI NW Karang Bata Kota Mataram Tahun Pelajaran 2020/2021".

\section{METODE}

Penelitian ini menggunakan pendekatan penelitian kualitatif dengan jenis penelitian deskriptif. Dalam penelitian ini, peneliti mengamati guru sebagai objek penelitian pada situasi pembelajaran di masa pandemi untuk memahami strategi yang digunakan guru. Sumber data penelitian ini adalah data yang berhubungan dengan strategi guru dalam mengatasi kesulitan belajar siswa pada masa pandemi Covid-19 di MI NW Karang bata Kota Mataram. Untuk

2 Siti Hidayatus Sholehah. "Minat belajar Siswa pada Mata Pelajaran Matematika kelas IV SD Negeri Karangtoro 04 Semarang". Jurnal Mimbar Ilmu, Vol. 23 Nomor 3, 2018, ISSN: 1829-8777X, hlm. 237.

${ }^{3}$ Guru MI NW Karang Bata, Wawancara, MI NW Karang Bata Kota Mataram, 02 Maret 2021.

${ }^{4}$ Guru MI NW Karang Bata, Dokumentasi, MI NW Karang Bata, 02 Maret 2021. 
mendapat data-data tersebut peneliti menentukan sumber data primer dan sekunder. Sumber data primer meliputi guru kelas IV MI NW Karang Bata, siswa kelas IV MI NW Karang Bata dan kepala sekolah atau yang mewakilkan. Sedangkan sumber data sekunder yang diambil dalam penelitian ini adalah nilai hasil belajar siswa dalam Ujian Akhir Semester (UAS) sebelum pandemi Covid-19 dan sesudah adanya pandemi Covid-19 serta Rencana Pelaksanaan Pembelajaran (RPP) mata pelajaran matematika.

Analisis data dalam penelitian dilakukan sejak terjun ke lapangan, observasi selama pelaksanaan penelitian di lapangan dan setelah selesai penelitian di lapangan. Analisis data dilakukan dengan cara mengorganisasi data yang diperoleh kedalam sebuah kategori, menjabarkan data kedalam unit-unit, menganalisis data yang penting, kemudian menyusun atau menyajikan data. ${ }^{5}$ Sedangkan pemerikasaan keabsahan data penelitian ini menggunakan teknik triangulasi.

\section{HASIL}

Pelaksanaan pembelajaran matematika di MI NW Karang Bata pada masa pandemi Covid-19 ini mendapat perhatian khusus dari pihak sekolah. Sistem pembelajaran yag diterapkan dalam proses kegiatan belajar mengajar di MI NW Karang Bata yang semula menggunakan pembelajaran daring beralih dengan menggunakan sistem pembelajaran luring atau tatap muka bergilir, sebagaimana telah diungkapkan oleh Bapak Muzakki selaku Kepala Madrasah MI NW Karang Bata bahwa:

"Pelaksanaan kegiatan pembelajaran di MI NW Karang Bata pada masa pandemi Covid19 menggunakan 2 tipe yaitu daring dan luring. Pada masa genting kemarin pihak madrasah menerapkan pembelajaran daring melalui whatsapp dan bagi yang tidak memiliki handphone datang ke sekolah untuk meminta penjelasan guru. Sedangkan sekarang telah beralih dengan menerapkan pembelajaran luring atau tatap muka bergilir. Tatap muka bergilir adalah kegiatan pembelajaran tatap muka yang dilakukan berselangseling, yaitu pada hari Senin, Selasa, Rabu untuk kelas I, II, III yang masuk sekolah dan hari Kamis, Jum'at, Sabtu merupakan jadwal masuk kelas IV, V. Bagi kelas VI dijadwalkan setiap hari masuk karena mempersiapkan menghadapi ujian di semester II."

Pada pelaksanaan pembelajaran matematika di kelas IV MI NW Karang Bata dijadwalkan khusus pada hari Sabtu pukul sebagaimana dipaparkan oleh Ibu Marzuki selaku guru kelas IV, "Karena mata pelajaran matematika perminggu telah ditentukan pemerintah sebanyak 6 jam pelajaran maka guru mengambil jadwal satu hari penuh yaitu pada hari Sabtu dari jam 7.30 -09.20 WITA atau 3 x 35 menit pada RPP Covid-19." '

Selain itu, berdasarkan hasil wawancara dan observasi yang dilakukan peneliti di MI NW Karang Bata bahwa pelaksanaan kegiatan belajar mengajar di kelas, guru telah melakukan strategi untuk mengatasi kesulitan belajar siswa pada mata pelajaran matematika selama masa pandemi Covid-19 ini. Berikut penjelasan mengenai strategi yang dilakukan guru dalam mengatasi kesulitan belajar matematika pada masa pandemi Covid-19 di kelas IV MI NW Karang Bata antara lain:

\section{a. Memastikan Kesiapan Siswa Untuk Belajar Matematika}

Sebelum proses pembelajaran matematika dimulai, saat bel berbunyi seluruh siswa masuk kelas pada pukul 07.30 WITA. Setelah memasuki kelas, siswa kemudian duduk ditempat duduknya masing-masing dan menunggu guru kelas datang. Keadaan kelas sebelum guru datang sedikit ramai, setelah guru masuk kelas keadaan kelas menjadi senyap dan siswa bersiap untuk memulai pembelajaran matematika. Guru memantau kedisiplinan siswa dengan melihat kerapian seragam, kelengkapan ikat pinggang, dasi dan kaos kaki. Selain itu guru juga meminta siswa mengamati sampah disekitar bangku mereka untuk membuangnya pada tempat

\footnotetext{
5Sugiyono. Metodelogi penelitian kuantitatif, Kualitatif dan RひD. (Bandung: Alfabeta, 2013)

${ }^{6}$ Guru MI NW Karang Bata, Hasil WawancaraMI NW karang Bata, 8 Oktober 2021

${ }^{7}$ Guru MI NW Karang Bata, MI NW karang Bata, 8 Oktober 2021.
} 
sampah agar suasana proses pembelajaran menjadi bersih, rapi dan nyaman sehingga siswa siap untuk memulai pembelajaran dengan baik. Kemudian guru mengajak siswa untuk tepuk semangat agar siswa-siswi tidak hanya siap untuk belajar namun juga semangat untuk menerima pelajaran matematika. ${ }^{8}$ Dengan penerapan strategi guru memastikan kesiapan belajar matematika siswa,akan menjadikan proses pembelajaran berjalan optimal. Sebab jika diawal pembelajaran siswa tidak siap belajar matematika maka materi yang dijelaskan guru akan sulit dipaham oleh siswa.

\section{b. Pemakaian Media Pembelajaran}

Pada dasarnya siswa dapat belajar matematika dengan mudah memahami materi jika menggunakan benda nyata yang mereka sering jumpai. Kesulitan siswa dalam pembelajaran matematika dikarenakan kurangnya pemahaman siswa terhadap materi, terutama pada masa pandemi siswa lebih banyak waktu untuk bermain dibandingkan dengan belajar. Dalam pembelajaran daring dimasa pandemi yang genting kemarin guru menggunakan media digital sebagai alat bantu siswa dalam belajar seperti video animasi pembelajaran dari youtube. Namun pada pembelajaran luring guru menerapan model pembelajaran matematika realistik yang dilakukan dengan memanfaatkan benda-benda konkret yang mudah siswa jumpai dan dibantu lingkungan sekitar siswa untuk mempermudah pemahaman mereka dalam mendalami materi.

Sesuai dengan data obervasi dan wawancara dalam proses pembelajaran guru sudah melibatkan penggunaan media pembelajaran terhadap siswa. Penerapan media pembelajaran secara kreatif dapat memberikan pengalaman belajar bagi siswa dan meningkatkan keterampilan sesuai dengan tujuan pembelajaran. Hal ini dinyatakan oleh guru kelas IV, "Beberapa siswa bergantian menjelaskan materi melalui media yang disediakan guru. Siswa tidak mengalami kesulitan dalam menggunakan media atau alat peraga, justru siswa merasa tertarik dalam menggunakannya, jika masih ada sebagian siswa yang belum mengerti maka guru akan membibing tersendiri siswa tersebut" Dengan penggunakan media pembelajaran akan mampu memudahkan siswa dalam memahami materi, karena siswa sulit membayangkan hal yang abstrak jika guru tidak membantunya dengan menggunakan media-media konkret atau nyata.

\section{c. Permasalahan yang diberikan berkaitan dengan kehidupan sehari-hari}

Pembelajaran matematika tidak terlepas dari permasalahan dalam kehidupan sehari-hari seperti soal cerita yang umumnya dikaitkan dengan lingkungan sekitar yang sesuai dengan pembelajaran matematika realistik. Dalam pembelajaran matematika permasalahan seperti ini sering ditemui siswa, sehingga guru mengaitkan pembelajaran dengan contoh nyata seperti materi pecahan. Dalam pembelajaran ini guru mencontohkan donat dan jambu kristal yang dipotong menjadi beberapa bagian. Selain itu, pada materi keliling persegi dan persegi panjang, guru meminta siswa mengamati benda sekitar untuk menyebutkan benda-benda apa saja yang berbentuk persegi dan persegi panjang. Kegiatan pembelajaran ini selain melatih keterampilan siswa juga dapat memperdalam tingkat pemahaman siswa terhadap materi yang diajarkan, karena siswa diberikan permasalahan yang ada di lingkungan sekitar mereka.

\section{d. Tingkat kesulitan Soal Sesuai Kemampuan Siswa}

Siswa dikatakan mengalami kesulitan belajar matematika jika tidak mampu menyelesaikan persoalan yang diberikan. Beberapa siswa kelas IV MI NW Karang Bata menyatakan bahwa "kesulitan yang dihadapi dalam mengerjakan persoalan dari guru disebabkan karena siswa tidak mampu memahami soal dan tingkat kesulitan soal terlalu tinggi". ${ }^{10}$

Terkait dengan kesulitan yang dialami siswa di kelas IV MI NW Karang Bata, siswa mengalami kesulitan belajar dalam pembelajaran matematika terkait dengan materi pecahan,

\footnotetext{
8 Hasil Observasi, Sabtu 9 Oktober 2021.

${ }^{9}$ Guru MI NW Karang Bata, Hasil Wawancara, MI NW karang Bata, 8 Oktober 2021.

${ }^{10}$ Guru MI NW Karang Bata, Hasil Wawancara, MI NW karang Bata, 9 Oktober 2021.
} 
keliling persegi dan persegi panjang, dan macam-macam bangun datar. ${ }^{11}$ Untuk materi pecahan siswa belum mampu mengalikan dan menyamakan penyebut. Pada materi keliling, siswa belum mampu menghitung keliling persegi panjang dengan rumus, Sedangkan pada materi bangun datar siswa belum mampu membedakan bentuk bangun datar beraturan dan bentuk tidak beraturan. Sehingga kesulitan-kesulitan yang dialami siswa tersebut di atasi oleh guru dengan menggunakan benda-benda kongkret yang ada di sekitar siswa. Namun kesulitan siswa secara keseluruhannya adalah dalam perkalian, sebagaimana dinyatakan oleh guru kelas IV yang memahami kesulitan siswa-siswi dalam proses pembelajaran yaitu:

"Kesulitan siswa dalam pembelajaran matematika di kelas IV adalah dalam perkalian. Karena perkalian adalah salah satu kunci utama mampu menguasai konsep matematika. Jika siswa belum menguasai perkalian maka siswa akan kesulitan dalam memahami materi selanjutnya maupun dalam mengerjakan soal." ${ }^{12}$

Strategi guru dalam mengatasi kesulitan siswa dalam perkalian ini adalah dengan melatih mereka melalui pertanyaan yang diberikan sesuai kemampuan mereka dari tingkat yang mudah, sedang dan sulit dengan menunjuk siswa untuk memicu kemampuan siswa menghitung perkalian dengan lancar. Karena pertanyaan yang dianggap mudah bagi siswa lain belum tentu siswa yang ditunjuk mampu menjawabnya dengan benar.

\section{e. Memberikan Kebebasan Siswa Untuk menyelesaikan masalah Sesuai dengan Kemampuan}

Tidak semua siswa memiliki kemampuan akademik yang sama. Berdasarkan hasil observasi peneliti, setelah memberikan penjelasan materi, guru memberikan kebebasan kepada siswa untuk menyelesaikan masalah yang diberikan guru sesuai dengan kemampuan mereka. Sebagaimana dinyatakan okeh siswa kelas IV, "dalam proses pembelajaran di kelas, Jika siswa mengalami kesulitan dalam menyelesaikan permasalahan, siswa diperbolehkan untuk berdiskusi dan bertanya dengan teman sebaya maupun dengan guru. ${ }^{13}$

Selain itu berdasarkan hasil observasi dalam pelaksanaan pembelajaran matematika yang dilakukan secara berdiskusi dengan guru memberikan beberapa soal yang harus diselesaikan secara berkelompok, terdapat kelompok yang menyelesaikan masalah dengan membagi tugas setiap anggota mengerjakan satu permasalahan adapula kelompok yang menyelesaikannya dengan bersama-sama. ${ }^{14} \mathrm{Hal}$ ini menunjukkan bahwa guru memberi kebebasan siswa dalam menyelesaikan masalah dengan tujuan hasil yang diperoleh benar dan siswa mampu menyelesaikannya dengan teman kelompok.

\section{f. Menghilangkan Rasa Takut Siswa Untuk Belajar Matematika}

Ketakutan siswa terhadap pembelajaran matematika terjadi pada beberapa siswa kelas IV MI NW Karang Bata karena siswa rata-rata mengalami kesulitan dalam belajar matematika. Hal ini dinyatakan oleh salah satu siswa dalam wawancara dengan peneliti, "salah satu mata pelajaran yang dianggap paling sulit adalah matematika". ${ }^{15}$ Maka dari itu guru mengatasi kesulitan tersebut dengan membuat proses pembelajaran menjadi menyenangkan, sebagaimana dijelaskan oleh Ibu Marzuki sbagai guru kelas IV yaitu:

"Dalam kegiatan pembelajaran matematika dilaksanakan dengan membuat suasana menyenangkan dan santai namun siswa tetap fokus dalam mengikuti pembelajaran. Pembelajaran ini dilakukan dengan kegiatan belajar sambil bermain dan menggunakan pendekatan Pendidikan Matematika Realistik (PMR) yaitu salah satu model pembelajaran

\footnotetext{
11 Hasil Observasi di MI NW Karang Bata, Sabtu 9 Oktober 2021.

${ }^{12}$ Guru MI NW Karang Bata, Hasil Wawancara, 8 Oktober 2021.

${ }^{13}$ Guru MI NW Karang Bata, Hasil Wawancara, MI NW karang Bata, 9 Oktober 2021.

${ }^{14}$ Hasil Observasi di MI NW Karang Bata, Sabtu 9 Oktober 2021.

${ }^{15}$ Guru MI NW Karang Bata, Hasil Wawancara, MI NW karang Bata, 9 Oktober 2021.
} 
yang menggunakan media benda nyata. Sehingga siswa menjadi nyaman, tidak bosan dan bersemangat dalam mengikuti proses pembelajaran matematika." ${ }^{16}$

Terkait dengan strategi guru dalam mengatasi kesulitan belajar siswa, dalam pelaksanaannya guru telah melakukan pembelajaran dengan menarik dan menyenangkan. Sesuai dengan hasil observasi peneliti, selama pembelajaran siswa memperhatikan guru dengan seksama dan tidak ada yang mengobrol sendiri. Guru meggunakan metode ceramah, diskusi dan demonstrasi. Perhatian siswa terfokus pada guru saat guru menjelaskan, jika siswa telah memahami materi guru mengajak siswa untuk mencari media di luar kelas dan memberikan kebebasan dalam menyalesaikan masalah, lalu siswa diminta menjelaskan hasilya di depan kelas.

Strategi yang digunakan oleh guru dalam proses pembelajaran matematika di kelas IV MI NW Karang Bata adalah strategi pembelajaran ekspositori dan strategi pembelajaran kooperatif. Strategi pembelajaran ekspositori atau biasa dikenal dengan metode ceramah, dalam hal ini guru lebih sering menjelaskan materi terlebih dahulu agar siswa memahami materi yang dijelaskan guru. Selain dengan strategi ekspositori, guru kelas IV MI NW Karang Bata juga menerapkan strategi kooperatif, sebagaimana sesuai dengan kegiatan pembelajaran dalam Rencana Pelaksanaan Pembelajaran (RPP). ${ }^{17}$ Langkah pelaksanaan strategi kooperatif dilakukan dengan metode diskusi, demonstrasi yang dikombinasikan dengan model pendekatan pendidikan matematika realistik pada materi-materi tertentu seperti pecahan, luas dan keliling bangun datar (persegi dan persegi panjang). ${ }^{18}$

Berdasarkan hasil pemaparan data temuan di atas dapat disimpulkan bahwa guru sudah mengupayakan untuk membuat pembelajaran matematika menarik dan menyenangkan. Siswa diajak untuk belajar sambil bermain, diberikan media untuk memahami materi, dan siswa dilatih atau dibimbing untuk mampu mengerjakan soal sesuai kemampuan mereka. Sehingga siswa terlihat antusias, semangat dan senang dalam mengikuti pembelajaran matematika di kelas.

\section{PEMBAHASAN}

Berdasarkan hasil pemaparan data di atas, kesulitan belajar matematika disebut juga dengan ketidakmampuan siswa dalam belajar matematika dikarenakan adanya suatu kondisi tertentu yang menghambat siswa untuk mencapai tujuan belajar. ${ }^{19}$ Terutama pada masa pandemi Covid-19 sistem pendidikan diubah berdasarkan Surat Edaran No 4 Tahun 2020 bahwa pembelajaran dilakukan secara daring. Sehingga siswa kelas IV MI NW Karang Bata memiliki berbagai kesulitan dalam proses belajar matematika. Dengan demikian guru memiliki peran penting dalam menerapkan strategi tertentu guna megatasi kesulitan belajar siswa pada masa pandemi Covid-19 di kelas IV MI NW Karang Bata tersebut.

Kegiatan pembelajaran matematika di kelas IV MI NW Karang Bata dijadwalkan secara rutin setiap seminggu sekali pada hari Sabtu. Pada masa pandemi Covid-19 ini pembelajaran sudah diperbolehkan dilakukan secara tatap muka namun dengan waktu pembelajaran yang sangat terbatas. Berdasarkan kebijakan sekolah, siswa kelas IV MI NW Karang Bata melaksanakan pembelajaran daring pada Bulan Maret 2020 sampai dengan bulan Juni 2021, namun pada tahun pelajaran 2020/2021 sekarang proses pembelajaran dilakukan melalui luar jaringan (luring) dengan jadwal masuk yaitu pada hari Kamis, Jum'at, Sabtu sedangkan pada hari Senin, Selasa, rabu digunakan untuk belajar dari rumah (daring) dengan mengerjakan tugas dari guru. Jadwal pada hari Kamis dan Jum'at adalah tema dan agama, sedangkan hari Sabtu dikhususkan untuk mata pelajaran matematika saja. Hal ini dikarenakan banyaknya materi

\footnotetext{
${ }^{16}$ Guru MI NW Karang Bata, Hasil Wawancara, MI NW karang Bata, 8 Oktober 2021.

${ }^{17}$ Rencana Pelaksanaan Pembelajaran Matematika, dokumentasi, Karang Bata, 11 Oktober 2021.

18 Hasil Observasi, Sabtu 9 Oktober 2021.

19 Mulyadi, Diagnosis Kesulitan Belajar \& Bimbingan Terbadap Kesulitan Belajar Khusus, (Yogyakarta: Nuha Litera), hlm. 174.
} 
matematika dengan ketentuan $6 \mathrm{JP} /$ minggu namun pembelajaran tatap muka hanya boleh dilakukan tidak lebih dari pukul 10.00 WITA. Sehingga guru memilih waktu satu hari penuh mulai dari 07.30 WITA - 09.20 WITA untuk melaksanakan proses pembelajaran matematika.

Dalam pelaksanakan proses pembelajaran matematika di masa Pandemi Covid-19 siswa mengalami penurunan prestasi dari sebelum adanya pandemi Covid-19 dan setelah adanya pandemi Covid-19. Penurunan tersebut dilihat dari nilai murni ujian semester genap tahun pelajaran 2018/2019 dengan ujian semester ganjil tahun pelajaran 2019/2020. Sehingga pada tahun ajaran baru ini guru melakukan beberapa strategi pada pembelajaran luring untuk mengatasi kesulitan siswa yang menyebabkan penurunan prestasi tersebut. Strategi guru merupakan suatu cara atau taktik yang dilakukan guru untuk mencapai suatu tujuan pembelajaran. ${ }^{20}$ Sehingga guru perlu melakukan persiapan yang matang sebelum melaksanakan kegiatan belajar-mengajar. Berikut adalah strategi pembelajaran yang diterapkan oleh guru kelas IV MI NW Karang Bata dalam mengatasi kesulitan belajar matematika pada masa pandemi Covid-19, yaitu:

\section{a. Strategi Pembelajaran Ekspositori}

Dalam hasil temuan peneliti, siswa kelas IV MI NW Karang Bata mengalami kesulitan belajar matematika pada masa pandemi Covid-19. Terutama pada pembelajaran daring, siswa mengalami hambatan dalam memahami materi yang dijelaskan guru melalui WhatsApp group meskipun di dukung dengan video animasi pembelajaran dari youtube. Tetapi ketika guru menerapkan strategi pembelajaran ekspositori pada pembelajaran luring dengan waktu yang terbatas dan materi cukup luas, siswa mampu memahami materi pembelajaran dengan maksimal dan memiliki semangat yang tinggi untuk belajar. Hal serupa dikemukakan oleh Wina sanjaya bahwa, "strategi pembelajaran ekspositori dianggap sangat efektif untuk mempelajari materi yang cukup luas dan waktu yang dimiliki untuk belajar terbatas". ${ }^{21}$

Langkah-langkah yang dilakukan guru kelas IV MI NW Karang Bata dalam menerapkan strategi ini dengan mengawali pembelajaran melalui menanya kesiapan belajar siswa, kemudian guru menjelaskan materi yang telah dipersiapkan sebelumnya dan di dukung dengan bantuan media pembelajaran. Setelah siswa dianggap paham dan dapat mengungkapkan kembali materi yang telah diuraikan dan proses pembelajaran sesuai dengan langkah-langkah kegiatan pembelajaran dalam RPP maka tujuan pembelajaran dapat dinyatakan tercapai.

\section{b. Strategi Pembelajaran Kooperatif}

Pada masa pandemi Covid-19 siswa memiliki hambatan dalam proses belajar matematika. Dalam mengatasi hambatan tersebut, guru kelas IV MI NW Karang Bata memilih menerapkan strategi pembelajaran kooperatif karena dianggap sesuai dengan karakteristik siswa dan materi pembelajaran. Guru lebih mudah membimbing dan mengarahkan siswa dalam bentuk kelompok, jika dalam sebuah kelompok ada siswa yang belum memahami penjelasan guru maka siswa yang sudah paham dapat berbagi ilmu dengan teman kelompok dan berdiskusi dalam penyelesaian masalah. Hal ini sesuai dengan pendapat Ridwan Abdullah Sani yang menyatakan, "pembelajaran kooperatif dapat menguntungkan siswa, karena siswa yang berkemampuan rendah dapat bekerjasama dan dibantu siswa pintar yang dapat menjadi tutor bagi yang berkemampuan rendah". ${ }^{22}$ Sehingga hal tersebut lebih efisien dilaksanakan oleh guru dalam pembelajaran luring di masa pandemi Covid-19.

Langkah-langkah yang dilakukan guru kelas IV dalam pelaksanaan strategi pembelajaran kooperatif adalah dengan membagi siswa menjadi beberapa kelompok, guru memberikan permasalahan yang harus siswa selesaikan ataupun dalam bentuk soal. Kemudian guru menjelaskan langkah-langkah kegiatan atau pengerjaannya, siswa berdiskusi dan

${ }^{20}$ J. Mursell dan S. Nasution, Mengajar Dengan Sukses, (Jakarta: PT. Bumi Aksara, 2006), hlm. 3.

21 Wina Sanjaya, Strategi Pembelajaran Berorientasi standar Proses Pendidikan, Jakarta: Prenadamedia grup, 2016), hlm.191.

22 Ridwan Abdullah Sani, Strategi Belajar Mengajar, (Depok: PT Raja Grafindo Persada, 2019), hlm.186. 
mempresentasikan di depan kelas. Strategi ini penting dilakukan karena "pembelajaran kooperatif mampu meningkatkan percaya diri siswa, menumbuhkan sikap kerjasama dan meningkatkan produktivitas mereka sehingga dapat meningkatkan prestasi belajar siswa". ${ }^{23} \mathrm{Hal}$ ini sesuai dengan pendekatan dalam kurikulum 2013 yaitu pendekatan saintifik, karena siswa yang berperan aktif selama proses pembelajaran berlangsung.

Selain strategi pembelajaran di atas, adapun strategi yang dilakukan guru kelas IV MI NW Karang Bata dalam mengatasi kesulitan belajar matematika di masa pandemi selama pembelajaran luring berlangsung di MI NW Karang Bata, antara lain:

\section{c. Memastikan kesiapan siswa untuk belajar matematika}

Memastikan kesiapan belajar siswa merupakan salah satu penerapan teori Thorndike dalam pembelajaran matematika. Sebelum melaksanakan proses pembelajaran, terlebih dahulu guru kelas IV MI NW Karang Bata memastikan kesiapan siswa dengan mengecek kerapian seragam siswa, meminta siswa membuang sampah yang ada di sekitar bangku mereka agar suasana kelas nyaman dan siap untuk belajar dan memberikan beberapa pertanyaan atau apersepsi. Pertanyaan yang diberikan guru seputar kabar, sudah sarapan atau belum, maupun pemahaman terhadap materi yang telah dipelajari. Hal ini penting dilakukan oleh guru sebelum memulai pembelajaran, karena setelah guru menerapkan strategi tersebut siswa menjadi siap menerima materi dan siswa memiliki minat belajar serta semangat belajar untuk mengikuti proses pembelajaran. Sebagaimana dikemukakan oleh Firliani dan kawan-kawan dalam pengaplikasian teori Thorndike, "bahwa siswa lebih minat belajar ketika mereka merasa berkebutuhan dan berkepentingan pada pembelajaran tersebut, maka guru harus memastikan bahwa kegiatan belajar tersebut penting bagi siswa." 24

\section{d. Pemakaian media belajar yang mempermudah pemahaman siswa}

Kesulitan belajar matematika yang dialami siswa di kelas IV adalah siswa sulit memahami materi yang dijelaskan oleh guru secara lisan. Siswa masih kebingungan dalam membayangkan persoalan yang dijelaskan guru. Namun setelah guru menggunakan model pembelajaran matematika realistik (PMR) melalui media pembelajaran benda-benda nyata, siswa mampu memahami materi yang dijelaskan oleh guru dan mampu meningkatkan minat siswa untuk belajar matematika. Sebagaimana dikemukakan oleh Mulyani Sumantri salah satu keuntungan menggunakan media konkret, "dapat meningkatkan minat siswa untuk belajar materi pelajaran dan memberikan pengalaman nyata yang menrangsang aktivitas diri sendiri untuk belajar" ${ }^{25}$

Menurut Hans Freudental "Matematika harus dikaitkan dengan realita dan matematika merupakan aktivitas manusia". ${ }^{26}$ Sehingga guru kelas IV MI NW Karang Bata menggunakan media kontret berupa donat dan jambu kristal pada materi pecahan dan benda di lingkungan kelas atau sekolah yang berbentuk persegi dan persegi panjang untuk materi keliling bangun datar persegi dan persegi panjang. Dalam materi pecahan, guru menjelaskan kepada siswa dengan menunjukkan sebuah donat yang bulat utuh, kemudian di bagi oleh dua teman sehingga mereka mendapatkan $1 / 2$ bagian. Setelah siswa memahami penjelasan guru, siswa diajak untuk berdiskusi dengan teman kelompok menggunakan media jambu kristal. Guru membagi kelompok dengan masing-masing kelompok terdiri dari 6 anggota, lalu siswa berdiskusi untuk menentukan sama-sama berapa bagian jambu kristal yang akan didapat oleh setiap anggota kelompok. Guru mengawasi jalannya diskusi dan meminta siswa mendemostrasikan hasilnya di depan kelas. Kegiatan pembelajaran dapat berjalan dengan baik dan siswa berhasil memahami konsep pecahan dengan mudah.

${ }^{23}$ Wahyudin Nur Nasution, Strategi Pembelajaran, (Medan: Perdana Publishing,2017), hlm.102.

${ }^{24}$ Firliani, dkk. "Teori Thorndike dan Implikasinya dalam Pembelajaran Matematika", Universitas Majalengka, Agustus 2019, hlm.831.

25 Mulyana Sumantri, Media Pembelajaran, (Bandung: Bumi Aksara, 2007), hlm. 178.

26 Seri Ningsih, "Realistic Mathematics Education: Model Alternatif Pembelajaran Matematika Sekolah”,IAIN Atasari Banjarmasin, Vol. 01, No. 02, Juni 2014, hlm.76. 


\section{e. Permasalahan yang diberikan merupakan permasalahan dalam kehidupan sehari- hari}

Dalam hasil temuan data peneliti, Kesulitan yang dialami siswa dalam pembelajaran matematika pada materi keliling bagun datar persegi dan persegi panjang adalah siswa belum mampu untuk menghafalkan rumus keliling. Sehingga guru mengajak siswa untuk mempraktikkan langsung pengukuran keliling benda di sekitar yang berbentuk persegi dan persegi panjang, strategi ini dilakukan oleh guru agar siswa tidak hanya sekedar menghafal rumus namun juga memahami konsep keliling, jika siswa mempraktikkan langsung, maka daya ingatan mereka akan jauh lebih lama dari pada hanya menghafal. Sebagaimana dikemukakan oleh Van de Henvel- Panhuizen, "bila anak belajar matematika terpisah dari pengalaman mereka sehari-hari maka anak akan cepat lupa dan tidak dapat mengaplikasikan matematika". ${ }^{27}$ Pada proses pembelajaran berlangsung, siswa diminta pergi keluar kelas untuk mencari benda yang berbentuk persegi dan persegi panjang, siswa diberi kebebasan dalam memilih dan mencari media tersebut. Dalam kegiatan ini siswa mengukur ubin, plat motor, plastik es, meja, dan lain-lain. Kemudian siswa berkumpul di halaman membuat lingkaran dan mempresentasikan hasil pengukurannya beserta benda yang diukur. Dengan menggunakan media tersebut, siswa mampu memahami materi dengan mudah, sehingga proses pembelajaran luring pada masa pandemi Covid-19 dapat berlangsung efektif.

\section{f. Tingkat kesulitan masalah sesuai dengan kemampuan anak}

Salah satu pertimbangan guru dalam memilih strategi pembelajaran adalah memahami karakteristik siswa. Dari hasil nilai ujian akhir semester sebelum pandemi Covid-19 dan setelah adanya pandemi Covid-19 siswa mengalami penurunan nilai. Hal ini dianggap siswa mengalami kesulitan mengerjakan soal karena belum memahami persoalan maupun materi dengan maksimal. Melihat kesulitan siswa tersebut, guru kelas IV MI NW Karang Bata mengadakan remidial bagi siswa yang belum mencapai nilai KKM dengan memberikan soal atau permasalahan yang akan siswa diskusikan dalam pembelajaran dengan tingkat yang lebih rendah sesuai dengan kemampuan karakteristik siswa. Bagi siswa yang telah mencapai nilai diatas KKM maka guru akan berikan pengayaan sesuai dengan tujuan pembelajaran, indikator dan materi pembelajaran sebagai penguatan.

Selain itu, dalam proses pembelajaran berlangsung guru kelas IV mempertimbangkan antara kemampuan siswa dengan materi pelajaran untuk merancang pembelajaran matematika yang tepat. Guru memberikan latihan soal dengan tingkat mudah, sedang dan sulit. Jika siswa mengalami kesulitan, guru akan berkeliling kelas dan membimbing siswa secara langsung di meja siswa. Sehingga siswa mampu memahami materi dengan maksimal dan meningkatnya motivasi mereka serta mampu memingkatkan perkembangan kognitif siswa. Hal serupa dikemukakan oleh Meriyati, "Pembelajaran dapat berhasil ketika guru mampu menyesuaikan tingkat kesulitan siswa dengan materi pembelajaran serta karakteristik siswa sehingga motivasi belajar mereka berada pada tingkat maksimal" 28

\section{g. Memberi kebebasan kepada anak untuk menyelesaikan masalah menurut caranya, atau sesuai dengan kemampuannya}

Siswa di kelas IV MI NW Karang Bata memiliki kemampuan yang berbeda-beda satu sama lain dalam memahami materi yang diberikan guru. Pada proses pembelajaran terdapat siswa yang cepat tanggap terhadap materi yang dijelaskan guru, namun ada pula yang perlu diulangi atau dijelaskan dengan pelan-pelan. Hal tersebut menyatakan bahwa karakteristik siswa tidak dapat disamakan. Dalam hal ini guru memberikan kebebasan siswa dalam menyelesaikan suatu permasalahan dengan caranya sendiri, guru tidak menuntut untuk siswa menyelesaikan masalah sesuai perintah guru. Guru lebih sering mengingatkan siswa dan

27 Evi Soviawati, "Pendekatan Matematika Realistik (PMR) untuk Meningkatkan Kemampuan Berfikir Siswa di Tingkat Sekolah Dasar”, Edisi Khusus No.2, Agustus 2011, hlm. 80.

28 Meriyati, Memahami Karakteristik Anak Didik, (Bandar Lampung: Fakta Press IAin Raden Intan lampung, 2015), hlm. 27. 
memberikan pilihan cara alternatif seperti dalam hal perkalian, mereka lebih mudah mengalikan dengan cara susun ataupun dengan penjumlahan berkelipatan. Sehingga siswa memiliki kebabasan dalam menyelesaikan permasalahan sesuai kemampuan mereka dan tetap dalam bimbingan guru. Hal tersebut mampu membuat siswa lebih ekspresif dan cepat menyelesaikan persoalan sesuai dengan kemampuan dan pemahaman mereka masing-masing, rasa jenuh akan berkurang dan siswa merasa nyaman dalam proses belajar karena tidak ada rasa ketakutan jika tidak bisa mengerjakan persoalan. Hal ini sesuai dengan pendapat Waqi'atul Fadlilah "apabila anak bekerja menurut kecepatannya sendiri, akan memungkinkan untuk membentuk inisiatif diri, mandiri, ekplorasi dan kebebasan belajar untuk mencapai hasil belajar yang optimal". ${ }^{29}$

\section{h. Menghilangkan Rasa Takut Siswa Untuk Belajar Matematika}

Pembelajaran matematika dapat dikatakan efektif jika dilakukan dengan adanya situasi serta kondisi belajar yang menyenangkan. Sebab siswa kelas IV MI NW Karang Bata merasa matematika merupakan salah satu mata pelajaran yang paling sulit. Dengan rasa ketakutan siswa terhadap pelajaran matematika tersebut, membuat siswa mengalami kesulitan dalam memahami materi pembelajaran. Siswa tidak menyukai matematika karena menganggap matematika adalah sulit sebab bersifat abstrak, padahal tidak semua materi pelajaran matematika sulit untuk dipelajari. Hal ini terjadi karena rasa ketakutan siswa yang membuat mereka sulit memahami dan mempelajari matematika.

Dalam mengatasi kesulitan siswa tersebut, pada proses pembelajaran guru kelas IV MI NW Karang Bata menerapkan strategi belajar sambil bermain. Guru berupaya membuat siswa menjadi nyaman belajar dengan melakukan permainan untuk menjadikan pembelajaran menyenangkan baik melalui bermain peran ataupun Aisbreaking di tengah-tengah pembelajaran agar siswa tidak bosan. Dalam proses atau akhir pembelajaran guru juga memberikan motivasi belajar kepada siswa. Sebelum mengakhiri pembelajaran dengan berdoa, guru memberikan pesan agar siswa selalu rajin belajar dan mengerjakan pekerjaan rumah (PR) maupun tugas. Dalam menjelaskan materi, guru berusaha membuat siswa paham dengan apa yang dijelaskan dan memberikan contoh dengan mengaitkan lingkungan sekitar siswa agar mudah dibayangkan dan dipahami oleh siswa. Selain itu bentuk motivasi yang dilakukan guru di kelas IV MI NW karang Bata adalah melakukan pendekatan kepada siswa dan bertanya terkait kesulitan yang dialami dalam proses belajar siswa. Guru telah berupaya dalam membuat proses pembelajaran menjadi menyenangkan sehingga mampu membuat siswa nyaman dalam mengikuti pembelajaran, walaupun masih terdapat beberapa siswa yang merasa takut terutama ketika adanya ujian matematika. Hal ini sesuai dengan pendapat Bunga Rampai, "kecemasan atau ketakutan siswa dapat diatasi jika guru dapat menciptakan suasana belajar yang menyenangkan dan bermakna bagi siswa agar tidak merasa takut untuk beajar matematika dan membuat siswa merasa nyaman". 30

Selama proses pembelajaran guru menerapkan strategi-strategi tersebut untuk mengatasi kesulitan belajar matematika pada siswa. Selain itu, guru juga menyampaikan materi ajar melalui metode diskusi dan demonstrasi pada proses pembelajaran matematika. Hal ini sesuai dengan pendapat $H$. Aswan bahwa "komponen strategi guru dalam pembelajaran salah satunya adalah metode pembelajaran. ${ }^{31}$ Dalam proses pembelajaran ini guru selalu melibatkan siswa dalam setiap kegiatan pembelajaran matematika. Pendekatan yang dilakukan guru berpusat pada siswa atau student centered learning. Berdasarkan kurikulum 2013 siswa dituntut untuk lebih aktif dengan dilibatkan dalam kegiatan bertanya-jawab, menggunakan media

29 Waqi'atul Fadlilah, "Self-Directed learning Of Islamic Kindergarten Students in Improving Multiple Children's Intergences”, Probolinggo, Vol. 10, Nomor 1, 2018, hlm. 47.

30 Bunga Rampai, Pengembangan Budaya Akademik Dosen Hasil kajian dan Hasil penelitian, (Jakarta: FTK YIN Syarif Hidayatullah Jakarta, 2018), hlm. 182.

${ }^{31}$ H. Aswan, Strategi Pembelajaran, (Yogtakarta: Aswaja Pressindo, 2016), hlm.20. 
pembelajaran serta diminta untuk menjelaskan pendapat tentang suatu materi baik secara lisan maupun tulisan.

Dari strategi-strategi di atas dapat disimpulkan bahwa strategi guru dalam mengatasi kesulitan belajar matematika pada masa pandemi Covid-19 di kelas IV MI NW Karang Bata adalah dengan menerapkan strategi pembelajaran ekspositori dan kooperatif. Adapun upaya dari guru MI NW Karang Bata untuk mampu menerapkan strategi tersebut adalah dengan memastikan kesiapan belajar siswa, menggunakan media pembelajaran realisik, permasalahan yang diberikan adalah permasalahan dalam kehidupan sehari-hari, tingkat kesulitan sesuai karakteristik anak, memberi kebebasan siswa untuk menyelesaikan dengan caranya sendiri, dan berupaya untuk mampu menghilangkan rasa takut siswa untuk belajar matematika.

\section{SIMPULAN DAN SARAN}

Berdasarkan pembahasan di atas maka dapat disimpulkan bahwa strategi yang dilakukan guru dalam mengatasi kesulitan belajar matematika pada masa pandemi Covid-19 di kelas IV MI NW Karang Bata yaitu strategi pembelajaran ekspositori dan strategi pembelajaran kooperatif dengan model pendidikan matematika realistik atau menggunakan benda-benda nyata. Selain itu, guru memiliki strategi sendiri dalam menerapkan strategi pembelajaran tersebut antara lain guru memastikan kesiapan belajar siswa, menggunakan media pembelajaran dengan benda-benda nyata, Permasalahan yang diberikan merupakan permasalahan dalam kehidupan sehari-hari, tingkat kesulitan masalah sesuai dengan kemampuan anak, dan memberi kebebasan kepada anak untuk menyelesaikan masalah menurut caranya atau sesuai dengan kemampuannya, serta menghilangkan rasa takut siswa untuk belajar matematika

Berdasarkan kesimpulan yang telah diuraikan di atas, terdapat beberapa saran dari peneliti terhadap strategi yang yang dilakukan guru dalam mengatasi kesulitan belajar matematika di kelas IV MI NW Karang Bata Kota Mataram, yaitu antara lain:

a. Kesulitan belajar matematika pada masa pandemi Covid-19 oleh siswa kelas IV MI NW Karang Bata merupakan hal yang perlu diperhatikan baik oleh pihak sekolah, guru, dan orang tua. Oleh karena itu pihak sekolah diharapkan memperhatikan proses pembelajaran matematika dengan menyediakan media-media pembelajaran yang dapat membantu guru dalam mempermudah menjelaskan materi pembelajaran.

b. Dalam penelitian ini tidak menguraikan bentuk-bentuk kesulitan belajar matematika pada jenjang sekolah dasar, maka diharapkan untuk peneliti selanjutnya mengkaji lebih dalam tentang bentuk-bentuk kesulitan belajar siswa khususnya pada mata pelajaran matematika jenjang sekolah dasar.

\section{REFERENSI}

Bunga Rampai, (2018), Pengembangan Budaya Akademik Dosen Hasil kajian dan Hasil penelitian, Jakarta: FTK YIN Syarif Hidayatullah Jakarta

Evi Soviawati, (2011) "Pendekatan Matematika Realistik (PMR) untuk Meningkatkan Kemampuan Berfikir Siswa di Tingkat Sekolah Dasar", Edisi Khusus No.2, Agustus 2011, hlm. 80

Firliani, dkk.(2019) "Teori Thorndike dan Implikasinya dalam Pembelajaran Matematika", Universitas Majalengka

Guru MI NW Karang Bata, Dokumentasi, MI NW Karang Bata, 02 Maret 2021. 
Guru MI NW Karang Bata, Wawancara, MI NW Karang Bata Kota Mataram, 02 Maret 2021.

H. Aswan, (2016), Strategi Pembelajaran, Yogtakarta: Aswaja Pressindo

Hasil Observasi di MI NW Karang Bata, Sabtu 9 Oktober 2021.

J. Mursell dan S. Nasution, (2006), Mengajar Dengan Sukses, Jakarta: PT. Bumi Aksara

Meriyati, (2015) Memahami Karakteristik Anak Didik, Bandar Lampung: Fakta Press IAin Raden Intan lampung

Mulyadi, Diagnosis Kesulitan Belajar dan Bimbingan Terhadap Kesulitan Belajar Kbusus, Yogyakarta: Nuha Litera

Mulyana Sumantri, (2007), Media Pembelajaran, Bandung: Bumi Aksara

Rencana Pelaksanaan Pembelajaran Matematika, dokumentasi, Karang Bata, 11 Oktober 2021.

Ridwan Abdullah Sani, (2019), Strategi Belajar Mengajar, Depok: PT Raja Grafindo Persada

Seri Ningsih, (2014) "Realistic Mathematics Education: Model Alternatif Pembelajaran Matematika Sekolah”,IAIN Atasari Banjarmasin, Vol. 01, No. 02, Juni 2014, hlm.76.

Siti Hidayatus Sholehah.(2018) "Minat belajar Siswa pada Mata Pelajaran Matematika kelas IV SD Negeri Karangtoro 04 Semarang". Jurnal Mimbar Ilmu, Vol. 23 Nomor 3, 2018, ISSN: 1829-8777X, hlm. 237.

Sugiyono. 2013Metodelogi penelitian kuantitatif, Kualitatif dan R\&D. Bandung: Alfabeta

Surat Edaran Mendikbud No. 2 Tahun 2020 Tentang Pelaksanaan Kewajiban Pendidikan Dalam Masa Darurat Penyebab Corona Virus Disease (Covid-19), Pusdiklat Pegawai Kementrian Pendidikan dan Kebudayaan, 24 Maret 2020", dalam https://pusdiklat.kemdikbud.go.id/surat-edaran-mendikbud-no-4-4tahun-2020-tentangpelaksanaan-kebijakan-pendidikan-dalam-masa-darurat-penyebarab-corona-virusdisease-Covid-19/. Diakses tanggal 01 April 2021, pukul 10.01 WITA.

Wahyudin Nur Nasution, (2017), Strategi Pembelajaran, Medan: Perdana Publishing

Waqi'atul Fadlilah, (2018) "Self-Directed learning Of Islamic Kindergarten Students in Improving Multiple Children's Intergences”, Probolinggo, Vol. 10, Nomor 1, 2018

Wina Sanjaya, (2016),Strategi Pembelajaran Berorientasi standar Proses Pendidikan, Jakarta: Prenadamedia grup, 